\title{
RISK EVALUATION OF WATER CONSERVANCY IN A PUBLIC-PRIVATE PARTNERSHIP PROJECT BASED ON GREY FUZZY THEORY
}

\author{
Bo WANG ${ }^{1,2,3}$, Nan $\mathrm{SHI}^{1}$, Fuqiang WANG ${ }^{1,2,3 *}$ and Xiangtian $\mathrm{NIE}^{1,2,3}$
}

\footnotetext{
${ }^{1}$ School of Water Conservancy, North China University of Water Resources and Electric Power, Zhengzhou 450046, China.

${ }^{2}$ Collaborative Innovation Center of Water Resources Efficient Utilization and Support Engineering, Zhengzhou 450046, China.

${ }^{3}$ Henan Key Laboratory of Water Environment Simulation and Treatment, Zhengzhou 450046, China

E-mail: wangfuqiang@ncwu.edu.cn
}

(Received May 2018; accepted July 2018)

Key words: grey fuzzy theory, PPP project, risk evaluation, rank correlation analysis, water conservancy project

\begin{abstract}
In this paper, a quantifiable method for risk evaluation of water conservancy ina publicprivate partnership (PP) PPP project is presented. Firstly, according to the characteristics of water conservancy PPP project, a risk evaluation index was determined by Delphi method and literature collection method; secondly, the weight of risk evaluation indexes were determined by rank correlation analysis; thirdly, based on grey fuzzy theory, a grey fuzzy comprehensive evaluation model was constructed, and uncertain grey and fuzzy contents were transformed into values that can be accurately measured, which provided a basis for managers to make decisions. Finally, the grey fuzzy comprehensive evaluation model was applied to Fendou Reservoir, a water conservancy PPP project, and it proved to be reasonable and scientific.
\end{abstract}

Palabras clave: teoría gris difusa, proyecto PPP, evaluación de riesgo, análisis de correlación de rangos, proyecto de conservación de agua

\section{RESUMEN}

En este trabajo se presenta un método de cuantificación para la evaluación de riesgo en un proyecto de colaboración pública y privada (PPP, por sus siglas en inglés) para conservación del agua. Primero, de acuerdo con las características del proyecto PPP para conservación del agua se determinó un índice de evaluación de riesgo por el método Delphi y una revisión de literatura; segundo, el peso de los índices de evaluación de riesgo se obtuvo por medio del análisis de correlación de rangos, y tercero, se construyó un modelo comprehensivo de evaluación gris difuso y los contenidos inciertos se transformaron en valores medibles con precisión para servir como fundamento a los tomadores de decisiones. Finalmente, el modelo comprehensivo gris disfuso se aplicó al embalse Fendou, un proyecto PPP de conservación del agua, y probó ser razonable y científico. 


\section{INTRODUCTION}

Water conservancy project has huge investment, large scale, long construction period, changeable construction environment and complex construction technology. To reduce the cost, make government funds more efficient and get rid of the shackles of social development caused by the shortage of water conservancy project funds, PPP (Public-PrivatePartnership), a new project financing model, has become more and more popular in the field of water conservancy project in China. Based on the experience of PPP model in Australia, Portugal, Spain and the UK, Garvin proved that PPP model has advantages in infrastructure development in North America (Garvin 2010, Nordin et al. 2017). It is reasonable and effective for the US to develop transportation facilities by the PPP model from the economic, legal and public point of view (Papajohn et al. 2010). A group researcher illustrated the positive effect of PPP model on the financial expenses of the provincial government in the project of Metro Line 4 in São Paulo, Brazil (Brandao et al. 2012, Roslan et al. 2017, Farooqi et al. 2017). Almassi tested the importance of Australian PPP concession contract setting and government guarantee mechanism to project performance using real option method (Ali et al. 2013, Toum et al. 2018).

PPP model is a new cooperation mode established by government and social capital through franchising. It has the characteristics of large investment, long operation cycle, complex contractual relationship and high social benefits. Shen et al. divided risks into internal, external and project-level risks by investigating the main risks in publicprojects and the management in the projects (Shen et al. 2006, Yun et al. 2018). Some researchers found that PPP project financing, especially capital market financing, plays an important role in the success of PPP projects (Regan et al. 2011, Arshadullah et al. 2017). In another study, scientists have constructed a PPP project performance index system with 5 kinds and 48 indexes by questionnaires (Yuan et al. 2011, Usman et al. 2017). Hwang et al. collected the risks that are common to PPP projects in Singapore and identified 23 key risks based on questionnaires (Hwang et al. 2013, Yasin and Usman 2017). A group researcher identified and counted 40 risks factors and selected the key risk factors of 20 water conservancy PPP projects in Ghana by Delphi method, mainly including exchange rate risk, corruption risk, theft risk, political risk, high cost operation and so on (Ameyaw and Chan, 2015).
Other researchers investigated and revealed the risk and PPP feasibility of the local government, as well as the risks in the stages of procurement, construction, operation and transfer by questionnaires and interviews (Shrestha et al. 2017, Li et al. 2018). Because of the extension of the PPP project in space and time, and the specialization of the water conservancy project, the water conservancy PPP project will have different risks from other models in the process of implementation. Finding out the risk factorscomprehensively and reasonably and determining the risk evaluation index system of water conservancy PPP project are very important to the success of the project.

The early international risk evaluation method was single, and foreign scholars used qualitative and quantitative methods to analyze the risk of PPP project. For example, Kumaraswamy established a selection model of the project team in the concession agreement to meet the requirements of the sustainable development of PPP project (Kumaraswamy and Zhang 2001, Lu et al. 2018). Grimsey constructed a risk assessment model of PPP project from different perspectives based on Monte Carlo method, and evaluated the effectiveness of the model through sensitivity analysis; based on FTA and Delphi method, Thomas proposed an evaluation framework for risk probability and risk impact; Shen embedded the guiding strategies of benefit-sharing, multi-party satisfaction and risksharing in the key issue of concession period under PPP model with mathematical methods such as simulation and game theory, which has opened up a new idea for the research related to PPP project concession (Grimsey and Lewis 2002, Shen et al. 2007, Thomas et al. 2006). Xue constructed a well-organized and feasible framework model for automatic concession decision-making, which has played a significant role in reducing the risk of PPP project (Xue 2009). Iyer constructed a hierarchical structure and internal relationship of risks by using Interpretative Structural Modeling (ISM), and then determined the correlation and influence of the risks through MICMAC analysis (Iyer and Sagheer 2010). Xie constructed a PPP project decision model based on multi-party satisfaction using Bayesian network, which provides effective decision support information for stakeholders by using Monte Carlo simulation method, Carbonara determined and evaluated the franchise period of PPP project by constructing a win-win model of risk sharing between public and private parties based on Method of Moments (MoM), Aristeidis constructed a model 
to evaluate the financial risk of PPP project, and made a probabilistic analysis of the risk based on sensitivity analysis and scenario analysis (Xie and Ng, 2013; Carbonara et al. 2014; Pantelias and Zhang 2010). The above researches confirm the importance of PPP project risk evaluation (Basak and Gajbhiye 2018, Yang et al. 2018). The risk research of water conservancy PPP project is mainly of qualitative description. There is a certain gap between the existing evaluation model and the actual project operation application at the present stage (Shen et al. 2017, Xue et al. 2016). The calculation process is complicated, and the evaluation result is not clear, which makes the risk evaluation of water conservancy PPP project still immature. Therefore, in this paper, based on grey fuzzy theory, a grey fuzzy comprehensive evaluation model of water conservancy PPP project was constructed, and uncertain grey and fuzzy contents were transformed into values that can be accurately measured, which provided a basis for managers to make decisions (Albrecht and Shaffer 2016, Lu et al. 2017).

\section{CONSTRUCTION OF THE RISK EVALUATION INDEX SYSTEM OF WATER CONSERVANCY PPP PROJECT}

On the basis of summarizing the existing risks, according to the characteristics of water conservancy PPP project, a risk evaluation index system of water conservancy PPP project was determined by Delphi method and literature collection method. The risk evaluation index system of water conservancy PPP project is shown in Fig. 1.

\section{DETERMINATION OF THE WEIGHT OF RISK EVALUATION INDEXES OF WATER CONSERVANCY PPP PROJECT BY RANK CORRELATION ANALYSIS}

Rank Correlation Analysis is a subjective weighting method combining qualitative and quantitative methods. In determining the index weight, AHP needs to establish the judgment matrix by expert assignment, and to meet the consistency requirements, but when the sample data are large, it is difficult to meet the consistency requirements. The rank correlation analysis and consistency check need not to establish the judgment matrix and the calculation is reduced, which is suitable for the case of large sample data and difficult to make complete quantitative analysis.

\section{Determination of the order relation of risk evalu- ation indexes}

The experts ranked the risk evaluation indexes at the same level $U_{1}, U_{2}, \ldots, U_{\mathrm{n}-1}$, Un from the most important to the least, namely, $U_{1}{ }^{*}>U_{2}{ }^{*}>\ldots>U_{\mathrm{n}-1}{ }^{*}>U_{\mathrm{n}}{ }^{*}$. Where $U_{\mathrm{i}}^{*}>U_{\mathrm{j}}^{*}$ showed that the risk evaluation index $i$ was not inferior to the risk evaluation index $j$ in importance, that is, the risk evaluation index $i$ was superior to or equal to the risk evaluation index $j$ in importance.

\section{Assignment of the degree of importance between risk evaluation indexes}

For the ratio of importance ri between adjacent risk evaluation indexes $U^{*} i-1$ and $U^{*} i$ at the same level, then:

$r_{i}=\omega_{i-1} / \omega_{i}$

Where $\omega_{\mathrm{i}-1}$ and $\omega_{\mathrm{i}}$ were the weights of the $i-1$ th and $i$ th risk evaluation indexes, respectively, $r_{\mathrm{i}}$ was usually assigned with $1 \sim 2$ values. The assignment and evaluation rules for $r_{\mathrm{i}}$ are shown in Table $\mathbf{I}$.

\section{Calculation of the weight of risk evaluation in- dexes}

According to Formula (1), Formula (2) below was obtained:

$\prod_{i=k}^{n} r_{i}=\frac{\omega_{k-1}}{\omega_{k}} \frac{\omega_{k}}{\omega_{k+1}} \cdots \frac{\omega_{n-2}}{\omega_{n-1}} \frac{\omega_{n-1}}{\omega_{n}}=\frac{\omega_{k-1}}{\omega_{n}}, \quad k \geq 2$

By finding the sum of $k$ from 2 to $n$, Formula (3) below was obtained:

$\sum_{k=2}^{n}\left(\prod_{i=k}^{n} r_{i}\right)=\sum_{k=2}^{n} \frac{\omega_{k-1}}{\omega_{n}}$

Since the sum of the weights of all risk evaluation indexes was 1, Formula (4) below was obtained from Formula (3):

$$
\begin{gathered}
1+\sum_{k=2}^{n}\left(\prod_{i=k}^{n} r_{i}\right)=1+\sum_{k=2}^{n} \frac{\omega_{k-1}}{\omega_{n}}=\frac{\omega_{n}}{\omega_{n}} \\
+\sum_{k=2}^{n} \frac{\omega_{k-1}}{\omega_{n}}=\frac{1}{\omega_{n}} \sum_{k=1}^{n} \omega_{k}=\frac{1}{\omega_{n}}
\end{gathered}
$$

By Formula (4), we know that the weight of other risk evaluation indexes can be deduced by calculating the weight of the last risk evaluation index $\omega_{\mathrm{n}}$. After deformation of Formula (4), Formula (5) below was obtained: 


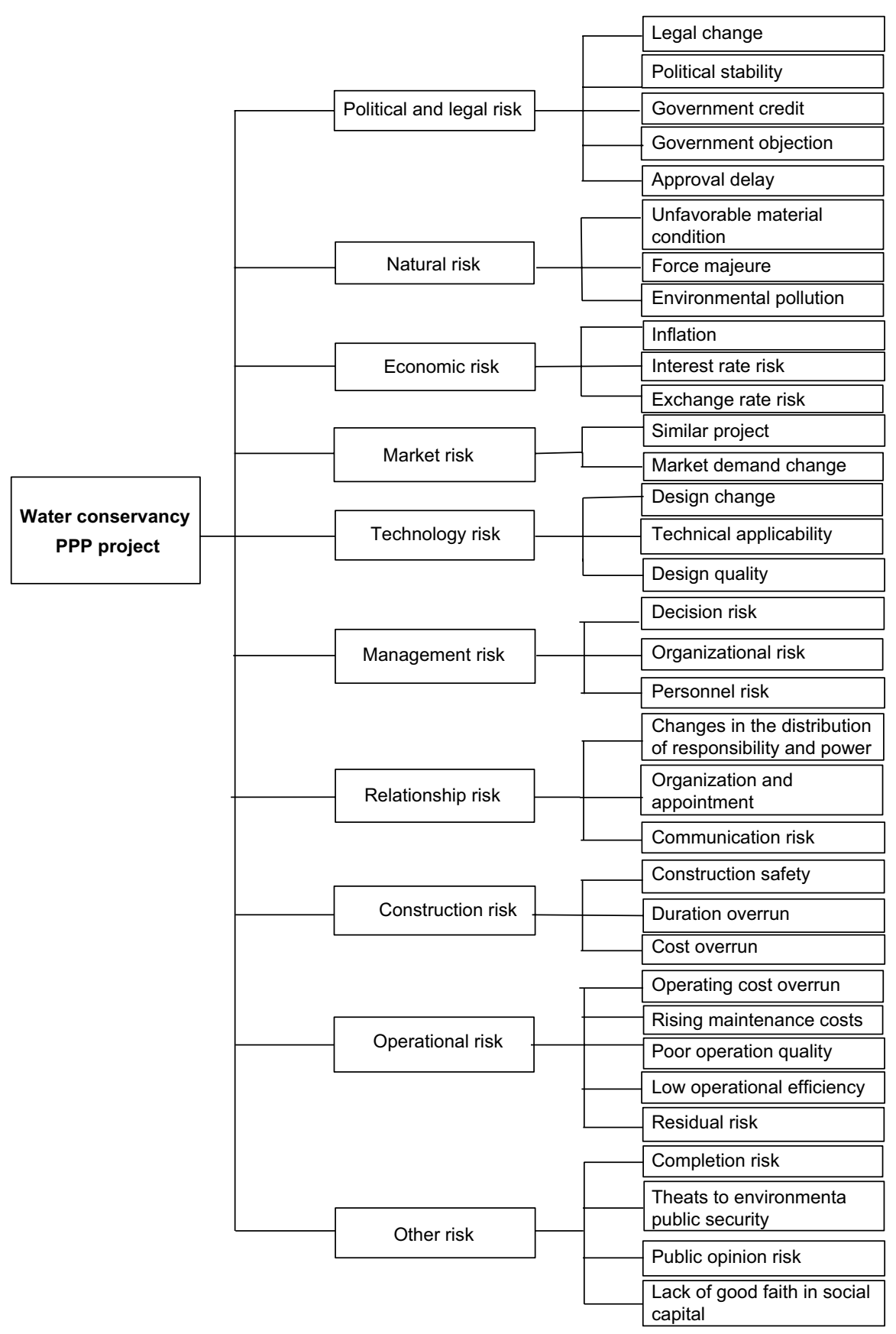

Fig. 1. A risk evaluation index system of water conservancy PPP project

$\omega_{n}=\left[1+\sum_{k=2}^{n}\left(\prod_{i=k}^{n} r_{i}\right)\right]^{1}$

The weight of other risk evaluation indexes can be deduced step by step by Formula (6) below:

$\omega_{n-1}=r n \omega n$

\section{Determination of the weight of risk evaluation indexes}

The weight of risk evaluation index $U_{\mathrm{i}}$ * was calculated by Rank Correlation Analysis. According to the corresponding relation between risk evaluation indexes and order relation evaluation indexes, the weight of risk evaluation indexes was determined. 
TABLE I. THE ASSIGNMENT AND EVALUATION RULES FOR $r_{\mathrm{I}}$

\begin{tabular}{ll}
\hline$r_{\mathrm{i}}$ & Evaluation instructions \\
\hline 1.0 & $U_{\mathrm{i}-1}^{*}$ is as important as $U^{*}{ }_{\mathrm{i}}$ \\
1.2 & $U^{*}{ }_{\mathrm{i}-1}$ and $U^{*}$ are a little important \\
1.4 & $U_{\mathrm{i}-1}^{*}$ and $U^{*}{ }_{\mathrm{i}}$ are comparatively important \\
1.6 & $U_{\mathrm{i}-1}^{*}$ and $U^{*}{ }_{\mathrm{i}}$ are very important \\
1.8 & $U_{\mathrm{i}-1}^{*}$ and $U^{*}{ }_{\mathrm{i}}$ are particularly important \\
\hline
\end{tabular}

Note: 1.1, 1.3, 1.5, 1.7 and 1.9 are between two adjacent scales

\section{CONSTRUCTION OF THE GREY FUZZY COMPREHENSIVE EVALUATION MODEL OF WATER CONSERVANCY PPP PROJECT}

\section{Determination of the risk evaluation index system and its weight}

On the basis of risk analysis and risk identification, a risk evaluation index system of water conservancy PPP project was constructed, and the weight of risk evaluation indexes of water conservancy PPP project was calculated by Rank Correlation Analysis.

Establishment of the fuzzy evaluation set and evaluation sample matrix

Fuzzy evaluation set is a set composed of risk evaluation of risk indexes by experts, which is generally expressed as $V$, that is, $V=\{V 1, \mathrm{~V} 2, \ldots$, $V h\}$, where $h$ is the number of experts. In the risk evaluation of water conservancy PPP project, the risk was generally divided into five levels: smaller risk, small risk, general risk, large risk, larger risk, and the corresponding evaluation grade $V$ was: $1,3,5,7,9$, that is, $V=(1,3,5,7,9)$. The risk between adjacent levels was $2,4,6,8$. According to the probability of risk occurrence in water conservancy PPP project, the experts evaluated the risk evaluation indexes and established an evaluation sample matrix.

$D=\left(d_{\mathrm{ij}}\right)$

Where $i=1,2, \ldots, h ; j=1,2, \ldots, m ; h$ was the number of experts; $m$ was the number of risk indexes.

\section{Determination of the evaluation grey class and grey evaluation coefficient}

In the risk evaluation of water conservancy PPP project, the risk was generally divided into five levels: smaller risk, small risk, general risk, large risk, larger risk, and the corresponding evaluation grey class e was: $1,2,3,4,5$. The whitening weight function is the degree to which a certain grey number inclines to a certain value within a certain range, and it mainly describes the degree to which an evaluation object is subordinate to a certain grey class. Suppose all the whitening weight functions were linear functions, the grey number corresponding to the risk level and the whitening weight function are shown in Table II.

To determine the grey evaluation coefficient, it was necessary to calculate the whitening weight function of the evaluation value in the evaluation sample matrix according to Table II. Suppose the grey evaluation coefficient of the eth evaluation grey class of the risk evaluation index $j$ by the $i$ th expert was $x_{\mathrm{ije}}$, the grey evaluation coefficient of the $e$ th evaluation grey class of the risk evaluation index $j$ by the experts was $x_{\mathrm{je}}$, and the grey evaluation coefficient of the risk evaluation index $j$ by the experts was $x_{\mathrm{j}}$, then:

$x_{i j e}=f e(d i j)$

TABLE II. THE GREY NUMBER CORRESPONDING TO THE RISK LEVEL AND THE WHITENING WEIGHT FUNCTION

\begin{tabular}{lcc}
\hline Risk level & $\begin{array}{c}\text { The grey } \\
\text { number }\end{array}$ & $\begin{array}{c}\text { Whitening } \\
\text { weight function }\end{array}$ \\
\hline $\begin{array}{l}\text { "small } \\
\text { risk" } e=1)\end{array}$ & $\otimes_{1} \in[0,1,4]$ & $f_{1}\left(d_{i j}\right)=\left\{\begin{array}{cc}0 & d_{i j} \notin[0,4] \\
1 & d_{i j} \in[0,1] \\
4 / 3-d_{i j} / 3 & d_{i j} \in(1,4]\end{array}\right.$ \\
\hline $\begin{array}{l}\text { "smaller } \\
\text { risk"(e=2) }\end{array}$ & $\otimes_{2} \in[0,3,6]$
\end{tabular}


$x_{j e}=\sum_{i=1}^{h} x_{i j e}$

$x_{j}=\sum_{i=1}^{h} \sum_{e=1}^{5} x_{i j e}$

Where $i=1,2, \ldots, h ; j=1,2, \ldots, m ; e=1,2,3,4,5$.

Determination of the membership degree and membership matrix

The membership cje of the risk evaluation index $\mathrm{j}$ to the grey scale e was determined, that is, the grey evaluation coefficient of the risk evaluation index $j$ was normalized, then:

$c_{j e}=\frac{\sum_{i=1}^{h} x_{i j e}}{\sum_{i=1}^{h} \sum_{e=1}^{5} x_{i j e}}$

The first-order fuzzy membership matrix $C_{\mathrm{b}}$ was:

$C_{b}=\left[c_{b j e}\right]=\left[c_{b 1 e}, c_{b 2 e}, \ldots, c_{b u_{b} e}\right]^{T}$

Where $b=1,2, \ldots, s, s$ was the number of secondlevel risk evaluation indexes, and $j=1,2, \ldots, u_{\mathrm{b}}, u_{\mathrm{b}}$ was the number of risk evaluation indexes corresponding to the second-level risk evaluation indexes in the first-level risk evaluation indexes.

\section{Fuzzy comprehensive evaluation}

The second-level fuzzy comprehensive evaluation was to convert the fuzzy vector $W b$ on the $U b$ to the fuzzy vector $B b$ on the $V$ by fuzzy linear conversion, that is:

$B_{b}=W_{b} C_{b}=\left[w_{b 1}, w_{b 2}, \ldots, w_{b u_{b}}\right]\left[c_{b 1 e}, c_{b 2 e}, \ldots, c_{b u_{b} e}\right]^{T}$

Then the judgment matrix was:

$B=[B 1, B 2, \ldots, B s]$

Similarly, the first-level fuzzy comprehensive evaluation was to convert the fuzzy vector $W$ on the $U$ to the fuzzy vector $R$ on the $V$ by fuzzy linear conversion, that is:

$R=W B=\left[w_{1}, w_{2}, \ldots, w_{s}\right]\left[B_{1}, B_{2}, \ldots, B_{s}\right]^{T}$

\section{Analysis of the evaluation result}

By multiplying the specific value R of fuzzy comprehensive evaluation by the quantitative evaluation index vector $V=(1,3,5,7,9)$, the comprehensive evaluation result $Q=R \cdot V$ of project risk was obtained. By comparing the risk evaluation indexes with the result of calculation, the risk grade of water conservancy PPP project was finally determined.

\section{CASE ANALYSIS}

\section{Project overview}

Fendou Reservoir is a proposed water conservancy PPP project in Heilongjiang Province in recent years. The total investment is about 1,426 million yuan, of which, the government contribution is 800 million yuan, and the social capital is 626 million yuan, accounting for $43.9 \%$ of the total investment; the total construction period is 36 months. Fendou Reservoir, a major water conservancy project with social capital participating in its construction and operation, has greatly reduced the national financial burden and made up for the lack of government financial funds. Through investment in infrastructure, the social capital can also obtain long-term and steady returns.

\section{Risk evaluation}

Establishment of the risk evaluation index system

According to the characteristics of Fendou Reservoir, a risk evaluation index system of Fendou Reservoir PPP project was determined by Delphi method and literature collection method. The risk evaluation index system of Fendou Reservoir PPP project is shown in Table III.

\section{Determination of the weight of risk evaluation indexes}

Five experts in the field of water conservancy PPP project were invited to rank and assign the first-level risk evaluation indexes of Fendou Reservoir PPP project from the most important to the least. The order relation and ratio of importance of the first-level risk evaluation indexes are shown in Table III.

According to the order relation of the first-level risk evaluation indexes, the weight of each index was calculated by the Formulas (5) and (6). The calculation result of the weight of the second-level risk evaluation indexes is shown in Table $\mathbf{V}$.

Similarly, the weight of the second-level risk evaluation indexes can be obtained. The calculation result of the weight of the second-level risk evaluation indexes is shown in Table III.

\section{Establishment of the evaluation sample matrix and determination of the evaluation grey class}

To evaluate the risk of Fendou Reservoir PPP project, five experts in the field of water conservancy PPP project were invited to rank the risk evaluation indexeson a scale of 1 to 9 . According to the formula of whitening weight function and the result of expert scoring, the grey evaluation coefficient of the risk evaluation indexes was calculated. The scoring of 
TABLE III. THE RISK EVALUATION INDEX SYSTEM OF FENDOU RESERVOIR PPP PROJECT

\begin{tabular}{|c|c|c|c|c|}
\hline Target layer & Criterion layer & Weight & Index layer & Weight \\
\hline \multirow{10}{*}{$\begin{array}{l}\text { Risk } \\
\text { evaluation } \\
\text { indexes } \\
\text { of Fendou } \\
\text { Reservoir } \\
\text { PPP project }\end{array}$} & $\begin{array}{l}\text { Political and legal } \\
\text { risk } U_{1}\end{array}$ & 0.208 & $\begin{array}{l}\text { Legal change } U_{11} \\
\text { Political stability } U_{12} \\
\text { Government credit } U_{13} \\
\text { Government objection } U_{14} \\
\text { Approval delay } U_{15}\end{array}$ & $\begin{array}{l}0.201 \\
0.135 \\
0.283 \\
0.194 \\
0.187\end{array}$ \\
\hline & Natural risk $U_{2}$ & 0.092 & $\begin{array}{l}\text { Unfavorable material condition } U_{21} \\
\text { Force majeure } U_{22} \\
\text { Environmental pollution } U_{23}\end{array}$ & $\begin{array}{l}0.306 \\
0.358 \\
0.336\end{array}$ \\
\hline & Economic risk $U_{3}$ & 0.173 & $\begin{array}{l}\text { Inflation } U_{31} \\
\text { Interest rate risk } U_{32} \\
\text { Exchange rate risk } U_{33} \\
\text { Financing risk } U_{34} \\
\text { Tax risk } U_{35}\end{array}$ & $\begin{array}{l}0.263 \\
0.190 \\
0.195 \\
0.244 \\
0.109\end{array}$ \\
\hline & Market risk $U_{4}$ & 0.062 & $\begin{array}{l}\text { Similar project competition } U_{41} \\
\text { Market demand change } U_{42}\end{array}$ & $\begin{array}{l}0.437 \\
0.529\end{array}$ \\
\hline & Technology risk $U_{5}$ & 0.031 & $\begin{array}{l}\text { Design change } U_{51} \\
\text { Technical applicability } U_{52} \\
\text { Design quality } U_{53}\end{array}$ & $\begin{array}{l}0.380 \\
0.345 \\
0.276\end{array}$ \\
\hline & Management risk $U_{6}$ & 0.109 & $\begin{array}{l}\text { Decision risk } U_{61} \\
\text { Organizational risk } U_{62} \\
\text { Personnel risk } U_{63}\end{array}$ & $\begin{array}{l}0.360 \\
0.338 \\
0.302\end{array}$ \\
\hline & Relationship risk $U_{7}$ & 0.07 & $\begin{array}{l}\text { Changes in the distribution of responsibility and power } U_{71} \\
\text { Organization and appointment } U_{72} \\
\text { Communication risk } U_{73}\end{array}$ & $\begin{array}{l}0.370 \\
0.314 \\
0.317\end{array}$ \\
\hline & Construction risk $U_{8}$ & 0.039 & $\begin{array}{l}\text { Construction safety } U_{81} \\
\text { Duration overrun } U_{82} \\
\text { Cost overrun } U_{83}\end{array}$ & $\begin{array}{l}0.298 \\
0.308 \\
0.394\end{array}$ \\
\hline & Operational risk $U_{9}$ & 0.117 & $\begin{array}{l}\text { Operating cost overrun } U_{91} \\
\text { Rising maintenance costs } U_{92} \\
\text { Poor operation quality } U_{93} \\
\text { Low operational efficiency } U_{94} \\
\text { Residual risk } U_{95}\end{array}$ & $\begin{array}{l}0.299 \\
0.169 \\
0.148 \\
0.175 \\
0.209\end{array}$ \\
\hline & Other risk $U_{10}$ & 0.098 & $\begin{array}{l}\text { Completion risk } \mathrm{U}_{101} \\
\text { Threats to environmental public security } U_{102} \\
\text { Public opinion risk } U_{103} \\
\text { Lack of good faith in social capital } U_{104}\end{array}$ & $\begin{array}{l}0.185 \\
0.222 \\
0.297 \\
0.295\end{array}$ \\
\hline
\end{tabular}

TABLE IV. THE ORDER RELATION AND RATIO OF IMPORTANCE OF THE FIRST-LEVEL RISK EVALUATION INDEXES

\begin{tabular}{lllllllllll}
\hline No. & The order relation of indexes & $r_{2}$ & $r_{3}$ & $r_{4}$ & $r_{5}$ & $r_{6}$ & $r_{7}$ & $r_{8}$ & $r_{9}$ & $r_{10}$ \\
\hline 1 & $U_{1}>U_{3}>U_{9}>U_{4}>U_{7}>U_{2}=U_{10}>U_{6}>U_{8}>U_{5}$ & 1.5 & 1.3 & 1.2 & 1.3 & 1.2 & 1 & 1.3 & 1.2 & 1.3 \\
2 & $U_{3}>U_{6}>U_{2}>U_{7}>U_{10}>U_{4}>U_{8}>U_{9}>U_{1}>U_{5}$ & 1.1 & 1.5 & 1.7 & 1.3 & 1.2 & 1.5 & 1.3 & 1.6 & 1.2 \\
3 & $U_{4}>U_{3}>U_{1}>U_{9}>U_{7}>U_{6}>U_{2}>U_{10}>U_{8}>U_{5}$ & 1.6 & 1.2 & 1.6 & 1.6 & 1.8 & 1.2 & 1.4 & 1.2 & 1.4 \\
4 & $U_{1}=U_{5}=U_{9}>U_{8}>U_{10}>U_{4}>U_{7}>U_{6}=U_{3}>U_{2}$ & 1 & 1 & 1.7 & 1.5 & 1.2 & 1.5 & 1.2 & 1 & 1.7 \\
5 & $U_{1}>U_{9}>U_{2}>U_{4}>U_{10}>U_{3}>U_{7}>U_{8}>U_{6}>U_{5}$ & 1.5 & 1.7 & 1.2 & 1.5 & 1.5 & 1.3 & 1.2 & 1.3 & 1.3 \\
\hline
\end{tabular}


the risk evaluation indexes and the calculation result are shown in Table VI.

\section{Fuzzy comprehensive evaluation}

(1) Second-level fuzzy comprehensive evaluation

By Formula (13), the comprehensive risk evaluation under the risk index $U_{\mathrm{i}}$ was calculated:

Similarly, by Formula (11), the fuzzy variable on the second-level risk evaluation index was calculated:

$$
B_{1}=W_{1} \times C_{1}=\left[\begin{array}{l}
0.201 \\
0.135 \\
0.283 \\
0.194 \\
0.187
\end{array}\right]^{T}\left[\begin{array}{lllll}
0.000 & 0.154 & 0.423 & 0.308 & 0.115 \\
0.650 & 0.350 & 0.000 & 0.000 & 0.000 \\
0.542 & 0.417 & 0.042 & 0.000 & 0.000 \\
0.083 & 0.417 & 0.417 & 0.083 & 0.000 \\
0.000 & 0.080 & 0.320 & 0.360 & 0.240
\end{array}\right]
$$

Similarly, the fuzzy variable $B$ on the second-level risk evaluation indexes was calculated by Formulas (11):

$B=\left[\begin{array}{l}B_{1} \\ B_{2} \\ B_{3} \\ B_{4} \\ B_{5} \\ B_{6} \\ B_{7} \\ B_{8} \\ B_{9} \\ B_{10}\end{array}\right]=\left[\begin{array}{lllll}0.257 & 0.292 & 0.238 & 0.145 & 0.068 \\ 0.181 & 0.359 & 0.327 & 0.106 & 0.027 \\ 0.379 & 0.360 & 0.147 & 0.087 & 0.026 \\ 0.092 & 0.341 & 0.371 & 0.128 & 0.035 \\ 0.393 & 0.462 & 0.146 & 0.000 & 0.000 \\ 0.344 & 0.500 & 0.156 & 0.000 & 0.000 \\ 0.215 & 0.476 & 0.235 & 0.046 & 0.031 \\ 0.197 & 0.492 & 0.272 & 0.040 & 0.000 \\ 0.333 & 0.482 & 0.172 & 0.012 & 0.000 \\ 0.233 & 0.318 & 0.270 & 0.133 & 0.045\end{array}\right]$

\section{(2) First-level fuzzy comprehensive evaluation}

By Formula (15), the calculation result of the first-level fuzzy comprehensive evaluation was $R=W \cdot B=\left[\begin{array}{lllll}0.276 & 0.386 & 0.223 & 0.082 & 0.030\end{array}\right]$, the grade vector of the evaluation grey class was $V=(1,3,5$, $7,9)^{\mathrm{T}}$, and the comprehensive evaluation result was $Q=R \cdot V=3.398$.

\section{Analysis of the evaluation result}

The comprehensive evaluation value of Fendou Reservoir PPP project was 3.398, which belonged to small risk, thus it was feasible. The main risks of the PPP project were political and legal risks and economic risks, which will directly affect the smooth progress of the whole PPP project. Therefore, great importance should be attached to them and corresponding risk countermeasures should be worked out.

\section{CONCLUSIONS}

In this paper, a quantifiable method for risk evaluation of water conservancy PPP project was presented. Firstly, according to the characteristics of water conservancy PPP project, a risk evaluation index system of water conservancy PPP project was determined by Delphi method and literature collection method; secondly, the weight of risk evaluation indexes of water conservancy PPP project was determined by Rank Correlation Analysis; thirdly, based on grey fuzzy theory, a grey fuzzy comprehensive evaluation model of water conservancy PPP project was constructed. Finally, the grey fuzzy comprehensive evaluation model was applied to Fendou Reservoir, a water conservancy PPP project, and it proved to be reasonable and scientific because the evaluation results were more objective, impartial and scientific for it can effectively reduce the influence of human factors in the evaluation, thus making the decision-making more scientific.

\section{ACKNOWLEDGMENTS}

The authors are grateful to the support of National Natural Science Foundation of China (No.51709116, No.51579101), the Key Scientific Research Projects of Henan Province Universities and Colleges

TABLE V. THE CALCULATION RESULT OF THE WEIGHT OF THE SECOND-LEVEL RISK EVALUATION INDEXES

\begin{tabular}{|c|c|c|c|c|c|c|c|c|c|c|}
\hline number & $w_{1}$ & $w_{2}$ & $w_{3}$ & $w_{4}$ & $w_{5}$ & $w_{6}$ & $w_{7}$ & $w_{8}$ & $w_{9}$ & $w_{10}$ \\
\hline 1 & 0.25 & 0.128 & 0.044 & 0.107 & 0.068 & 0.166 & 0.034 & 0.068 & 0.053 & 0.082 \\
\hline 2 & 0.16 & 0.06 & 0.241 & 0.04 & 0.016 & 0.094 & 0.031 & 0.019 & 0.265 & 0.073 \\
\hline 3 & 0.107 & 0.171 & 0.328 & 0.018 & 0.031 & 0.037 & 0.205 & 0.013 & 0.022 & 0.067 \\
\hline 4 & 0.2 & 0.079 & 0.036 & 0.036 & 0.021 & 0.118 & 0.044 & 0.065 & 0.2 & 0.2 \\
\hline 5 & 0.325 & 0.023 & 0.216 & 0.106 & 0.018 & 0.127 & 0.036 & 0.03 & 0.047 & 0.071 \\
\hline weight & 0.208 & 0.092 & 0.173 & 0.062 & 0.031 & 0.109 & 0.07 & 0.039 & 0.117 & 0.098 \\
\hline
\end{tabular}


RISK EVALUATION BASED ON GREY FUZZY THEORY

TABLE VI. THE SCORING OF THE RISK EVALUATION INDEXES AND THE CALCULATION RESULT

\begin{tabular}{|c|c|c|c|c|c|c|c|c|c|c|c|c|c|c|c|c|}
\hline $\begin{array}{l}\text { Risk } \\
\text { index }\end{array}$ & $d_{1 \mathrm{j}}$ & $d_{2 \mathrm{j}}$ & $d_{3 \mathrm{j}}$ & $d_{4 \mathrm{j}}$ & $d_{5 \mathrm{j}}$ & $x_{\mathrm{j} 1}$ & $x_{\mathrm{j} 2}$ & $x_{\mathrm{j} 3}$ & $x_{\mathrm{j} 4}$ & $x_{\mathrm{j} 5}$ & $x_{\mathrm{ij}}$ & $c_{\mathrm{j} 1}$ & $c_{\mathrm{j} 2}$ & $c_{\mathrm{j} 3}$ & $c_{\mathrm{j} 4}$ & $c_{\mathrm{j} 5}$ \\
\hline$U_{11}$ & 7 & 5 & 4 & 5 & 6 & 0 & 1.333 & 3.667 & 2.667 & 1.000 & 8.667 & 0 & 0.154 & 0.423 & 0.308 & 0.115 \\
\hline$U_{12}$ & 1 & 2 & 2 & 1 & 1 & 4.333 & 2.333 & 0 & 0 & 0 & 6.667 & 0.650 & 0.350 & 0 & 0 & 0 \\
\hline$U_{13}$ & 2 & 3 & 2 & 2 & 1 & 4.333 & 3.333 & 0.333 & 0 & 0 & 8.000 & 0.542 & 0.417 & 0.042 & 0 & 0 \\
\hline$U_{14}$ & 5 & 5 & 4 & 3 & 3 & 0.667 & 3.333 & 3.333 & 0.667 & 0 & 8.000 & 0.083 & 0.417 & 0.417 & 0.083 & 0 \\
\hline$U_{15}$ & 8 & 7 & 4 & 6 & 5 & 0 & 0.667 & 2.667 & 3.000 & 2.000 & 8.333 & 0 & 0.080 & 0.320 & 0.360 & 0.240 \\
\hline$U_{21}$ & 4 & 3 & 3 & 2 & 5 & 1.333 & 3.667 & 2.333 & 0.333 & 0 & 7.667 & 0.174 & 0.478 & 0.304 & 0.043 & 0 \\
\hline$U_{22}$ & 5 & 7 & 5 & 5 & 5 & 0 & 1.333 & 4.667 & 2.333 & 0.667 & 9.000 & 0 & 0.148 & 0.519 & 0.259 & 0.074 \\
\hline$U_{23}$ & 2 & 3 & 1 & 2 & 4 & 2.667 & 3.333 & 1.000 & 0 & 0 & 7.000 & 0.381 & 0.476 & 0.143 & 0 & 0 \\
\hline$U_{31}$ & 1 & 2 & 2 & 3 & 1 & 3.667 & 3.000 & 0.333 & 0 & 0 & 7.000 & 0.524 & 0.429 & 0.048 & 0 & 0 \\
\hline$U_{32}$ & 1 & 3 & 2 & 3 & 2 & 3.000 & 3.667 & 0.667 & 0 & 0 & 7.333 & 0.409 & 0.500 & 0.091 & 0 & 0 \\
\hline$U_{33}$ & 2 & 1 & 2 & 3 & 2 & 4.333 & 3.333 & 0.333 & 0 & 0 & 8.000 & 0.542 & 0.417 & 0.042 & 0 & 0 \\
\hline$U_{34}$ & 7 & 5 & 6 & 5 & 5 & 0 & 1.000 & 4.000 & 3.333 & 1.000 & 9.333 & 0 & 0.107 & 0.429 & 0.357 & 0.107 \\
\hline$U_{35}$ & 2 & 3 & 1 & 2 & 2 & 4.333 & 3.333 & 0.333 & 0 & 0 & 8.000 & 0.542 & 0.417 & 0.042 & 0 & 0 \\
\hline$U_{41}$ & 7 & 5 & 5 & 5 & 4 & 0 & 1.667 & 4.000 & 2 & 0.667 & 8.333 & 0 & 0.200 & 0.480 & 0.240 & 0.080 \\
\hline$U_{42}$ & 5 & 3 & 4 & 2 & 3 & 1.333 & 3.667 & 2.333 & 0.333 & 0 & 7.667 & 0.174 & 0.478 & 0.304 & 0.043 & 0 \\
\hline$U_{51}$ & 3 & 4 & 3 & 2 & 4 & 1.333 & 4.000 & 1.667 & 0 & 0 & 7.000 & 0.190 & 0.571 & 0.238 & 0 & 0 \\
\hline$U_{52}$ & 1 & 2 & 2 & 1 & 1 & 4.333 & 2.333 & 0 & 0 & 0 & 6.667 & 0.650 & 0.350 & 0 & 0 & 0 \\
\hline$U_{53}$ & 4 & 1 & 2 & 2 & 4 & 2.333 & 3.000 & 1.333 & 0 & 0 & 6.667 & 0.350 & 0.450 & 0.200 & 0 & 0 \\
\hline$U_{61}$ & 3 & 2 & 4 & 1 & 2 & 2.667 & 3.333 & 1.000 & 0 & 0 & 7.000 & 0.381 & 0.476 & 0.143 & 0 & 0 \\
\hline$U_{62}$ & 3 & 4 & 2 & 2 & 3 & 2.000 & 4.000 & 1.333 & 0 & 0 & 7.333 & 0.273 & 0.545 & 0.182 & 0 & 0 \\
\hline$U_{63}$ & 4 & 3 & 1 & 2 & 2 & 2.667 & 3.333 & 1.000 & 0 & 0 & 7.000 & 0.381 & 0.476 & 0.143 & 0 & 0 \\
\hline$U_{71}$ & 7 & 4 & 4 & 3 & 3 & 0.667 & 3.333 & 2.333 & 1.000 & 0.667 & 8.000 & 0.083 & 0.417 & 0.292 & 0.125 & 0.083 \\
\hline$U_{72}$ & 3 & 2 & 1 & 1 & 3 & 3.333 & 3.333 & 0.667 & 0 & 0 & 7.333 & 0.455 & 0.455 & 0.091 & 0 & 0 \\
\hline$U_{73}$ & 4 & 3 & 4 & 3 & 3 & 1.000 & 4.333 & 2.333 & 0 & 0 & 7.667 & 0.130 & 0.565 & 0.304 & 0 & 0 \\
\hline$U_{81}$ & 3 & 3 & 3 & 3 & 3 & 1.667 & 5.000 & 1.667 & 0 & 0 & 8.333 & 0.200 & 0.600 & 0.200 & 0 & 0 \\
\hline$U_{82}$ & 5 & 4 & 4 & 5 & 4 & 0 & 2.667 & 4.000 & 1.000 & 0 & 7.667 & 0 & 0.348 & 0.522 & 0.130 & 0 \\
\hline$U_{83}$ & 3 & 1 & 3 & 2 & 3 & 2.667 & 4.000 & 1.000 & 0 & 0 & 7.667 & 0.348 & 0.522 & 0.130 & 0 & 0 \\
\hline$U_{91}$ & 3 & 2 & 2 & 3 & 2 & 2.667 & 4.000 & 1.000 & 0 & 0 & 7.667 & 0.348 & 0.522 & 0.130 & 0 & 0 \\
\hline$U_{92}$ & 3 & 1 & 2 & 1 & 3 & 3.333 & 3.333 & 0.667 & 0 & 0 & 7.333 & 0.455 & 0.455 & 0.091 & 0 & 0 \\
\hline$U_{93}$ & 4 & 5 & 3 & 5 & 3 & 0.667 & 3.333 & 3.333 & 0.667 & 0 & 8.000 & 0.083 & 0.417 & 0.417 & 0.083 & 0 \\
\hline$U_{94}$ & 4 & 2 & 1 & 2 & 3 & 2.667 & 3.333 & 1.000 & 0 & 0 & 7.000 & 0.381 & 0.476 & 0.143 & 0 & 0 \\
\hline$U_{95}$ & 3 & 2 & 2 & 3 & 3 & 2.333 & 3.333 & 1.000 & 0 & 0 & 6.667 & 0.350 & 0.500 & 0.150 & 0 & 0 \\
\hline$U_{101}$ & 5 & 3 & 2 & 5 & 1 & 2.000 & 2.667 & 1.667 & 0.667 & 0 & 7.000 & 0.286 & 0.381 & 0.238 & 0.095 & 0 \\
\hline$U_{102}$ & 1 & 2 & 2 & 1 & 2 & 4.333 & 2.333 & 0 & 0 & 0 & 6.667 & 0.650 & 0.350 & 0 & 0 & 0 \\
\hline$U_{103}$ & 5 & 3 & 4 & 2 & 5 & 0.667 & 3.333 & 3.333 & 0.667 & 0 & 8.000 & 0.083 & 0.417 & 0.417 & 0.083 & 0 \\
\hline$U_{104}$ & 6 & 7 & 6 & 5 & 3 & 0.333 & 1.333 & 3.000 & 2.667 & 1.333 & 8.667 & 0.038 & 0.154 & 0.346 & 0.308 & 0.154 \\
\hline
\end{tabular}

(No.17B570003), Distinguished Young Scholar of Science and Technology Innovation (184100510014) and Foundation for Dr in North China University of Water Resources and Electric Power (No.10030). Special thanks for the reviewers and their constructive comments and suggestions in improving the quality of this manuscript.

\section{REFERENCES}

Albrecht F. and Shaffer G. (2016). Regional Sea-Level Change along the Chilean Coast in the 21st Century. Journal of Coastal Research. 32 (6), 1322-1332.
Ali A., Brenda M. and Matthew T. (2013). Real optionsbased approach for valuation of government guarantees in public-private partnerships. Journal of Infrastructure Systems. 19 (2), 196-204.

Ameyaw E.E. and Chan A.P.C. (2015). Evaluating key risk factors for PPP water projects in Ghana: a Delphi study. Journal of Facilities Management. 13 (2), 133-155.

Arshadullah M., Suhaib M., Baber R., Usama M., Zaman B., Mahmood I.A., Hyder S.I. (2017). Growth of Chenopodium quiona Wild under Naturally Salt Affected Soils. Malaysian Journal of Sustainable Agriculture. 1(1), 01-03.

Basak B.B. and Gajbhiye N.A. (2018). Herbage yield and bioactive principle of senna as influenced by 
micronutrient application in soil. Journal of Environmental Biology. 39 (1):43-49.

Brandão L.E., Pinto C.B. and Gomes L.L. (2012). Government supports in public-private partnership contracts: Metro line 4 of the São Paulo subway system. Journal of Infrastructure Systems. 18 (3), 218-225.

Carbonara N., Costantino N. and Pellegrino R. (2014). Concession period for PPPs: A win-win model for a fair risk sharing. International Journal of Project Management. 32 (7), 1223-1232.

Farooqi Z.U.R., Nasir M.S., Nasir A., Zeeshan N., Ayub I., Rashid H., Qamar M.U., Sarwar A. and Akram M.A. (2017). Evaluation and analysis of traffic noise in different zones of Faisalabad - an industrial city of Pakistan. Geology, Ecology, and Landscapes. 1(4), 232-240.

Garvin M.J. (2010). Enabling Development of The Transportation Public-Private Partnership Market in The United States. Journal of Construction Engineering and Management. 136 (4), 402-411.

Grimsey D. and Lewis M.K. (2002). Evaluating the risks of public private partnerships for infrastructure projects. International Journal of Project Management. 20 (2), 107-118.

Hwang B.G., Zhao X. and Gay M.J.S. (2013). Public private partnership projects in Singapore: Factors, critical risks and preferred risk allocation from the perspective of contractors. International Journal of Project Management. 31 (3), 424-433.

Iyer K.C. and Sagheer M. (2010). Hierarchical structuring of PPP risks using interpretative structural modeling. Journal of Construction Engineering and Management. 136 (2), 151-159.

Kumaraswamy M.M. and Zhang X.Q. (2001). Governmental role in BOT-led infrastructure development. International Journal of Project Management. 19 (4), 195-205.

Li Y., Yang P. and Wang H. (2018). Collecting Coal-Fired Power Environmental Tax to Promote Wind Power Development and Environmental Improvement. Acta Scientifica Malaysia. 2(1), 5-8.

Lu X.H., Jensen K.H., Jin M.G. and Wang P.F. (2017). Effect of unsaturated flow model conceptualization on the dynamic response of an integrated distributed hydrological model. Applied Ecology and Environmental Research. 15 (3), 91-103.

Lu Z., Daxing X. and Hailun W. (2018). Two-Stage Cubature Kalman Filterand Its Application in Water Pollution Model. Acta Scientifica Malaysia. 2(1), 9-13.

Nordin N.F.H., Idris S.N.N.M., Nawi M.N.M., John A. and Chowdhury A.J.K. (2017). Pcb Biodegration Using Bacteria Isolated from Landfill Leachate. Science Heritage Journal. 1(2), 8-11.

Pantelias A. and Zhang Z. (2010). Methodological framework for evaluation of financial viability of public-private partnerships: Investment risk approach. Journal of Infrastructure Systems. 16 (4), 241-250.

Papajohn D., Cui Q. and EmreBayraktar M. (2010). PublicPrivate Partnerships in U.S. transportation: Research overview and a path forward. Journal of Management in Engineering, 27 (3), 126-135.

Regan M., Smith J. and Love P.E.D. (2011). Impact of the capital market collapse on public-private partnership infrastructure projects. Journal of Construction Engineering and Management. 137 (1), 6-16.

Roslan M.A.M., Mohamad M.A.N. and Omar S.M. (2017). High-Quality Dna From Peat Soil for Metagenomic Studies: A Minireview On Dna Extraction Methods. Science Heritage Journal. 1(2), 1-7.

Shen L.Y., Bao HJ. and Wu Y.Z. (2007). Using bargaininggame theory for negotiating concession period for BOT-type contract. Journal of Construction Engineering and Management. 133 (5), 385-392.

Shen L.Y., Platten A. and Deng X.P. (2006). Role of public private partnerships to manage risks in public sector projects in Hong Kong. International Journal of Project Management. 24 (7), 587-594.

Shen Y., Mi W. and Zhang Z. (2017). A positioning lockholes of container corner castings method based on image recognition. Polish Maritime Research. 24 (SI), 95-101.

Shrestha A., Chan T.K. and Aibinu A.A. (2017). Risks in PPP water projects in China: Perspective of local governments. Journal of Construction Engineering and Management. 143 (7), 0501-7006.

Thomas A.V., Satyanarayana N., Kalidindi L.S. and Ganesh. (2006). Modelling and assessment of critical risks in BOT road projects. Construction Management and Economics. 24 (4), 407-424.

Toum G.A.E., Yassin M.I., Dagash, and Mahagoub S.A. (2018). Nitrogen Use Efficiency of Three Maize (Zea Mays L.) Cultivars. Malaysian Journal of Sustainable Agriculture. 2(1), 12-14.

Usman M., Yasin H., Nasir A. and Mehmood W. (2017). A Case Study of Groundwater Contamination Due to Open Dumping of Municipal Solid Waste in Faisalabad, Pakistan. Earth Sciences Pakistan. 1(2), 12-13.

Xie J. and Ng S.T. (2013). Multiobjective bayesian network model for public-private partnership decision support. Journal of Construction Engineering and Management. 139 (9), 1069-1081.

Xue G., Liu Y.J., Zhang M.Q., Zhang W., Zhang J., Luo H.Q. and Jia R. (2016). Optimal design and numerical simulation on fish-like flexible hydrofoil propeller. Polish Maritime Research. 23 (4), 59-66.

Xue Z. (2009). Win-Win concession period determination methodology. Journal of Construction Engineering and Management. 135 (6), 550-558. 
Yang Y., Zhong M., Yao H., Yu F., Fu X. and Postolache O. (2018). Internet of things for smart ports: Technologies and challenges. IEEE Instrumentation \& Measurement Magazine. 21 (1), 34-43.

Yasin H. and Usman M. (2017). Site investigation of open dumping site of Municipal Solid Waste in Faisalabad. Earth Science Pakistan. 1(1), 25-27.
Yuan J., Wang C. and Skibniewski M.J. (2011). Developing key performance indicators for public-private partnership projects: Questionnaire survey and analysis. Journal of Management in Engineering. 28 (3), 252-264.

Yun G., Williams S. and Wenbin D. (2018). Integrating Two-Stage Up-Flow Anaerobic Sludge Blanket with A Single-Stage Aerobic Packed-Bed Reactorfor Raw Palm Oil Mill Effluent Treatment. Malaysian Journal of Sustainable Agriculture. 2(1), 15-18. 